\title{
Finding new medicines to fight CF: multiple steps of a success story
}

\author{
Margarida D Amaral ${ }^{1,2}$ \\ From 6th European Conference on Rare Diseases and Orphan Products \\ Brussels, Belgium. 23-25 May 2012
}

\section{Background}

Cystic fibrosis (CF) is a major life-limiting genetic disease leading to severe respiratory symptoms caused by mutations in CF trans membrane conductance regulator (CFTR), a chloride channel expressed at the apical membrane of epithelial cells. Absence of functional CFTR from the surface of respiratory cells reduces mucociliary clearance, promoting airways obstruction, chronic infection and ultimately lung failure [1]. Despite major clinical advances treating the symptoms, which pushed survival beyond the second decade ( 25 years in Europe), CF is still a life-limiting condition [2]. However, to further increase CF patients life expectancy, CF needs to be treated beyond its symptoms, i.e., through treatments addressing the basic defect associated with CFTR gene mutations [3]. So far $\sim 1,900$ CFTR mutations were reported [4], but one single mutation, F508del remains the most common one, as it occurs in $\sim 90 \%$ of CF patients in at least one allele [5] and is associated with a severe clinical phenotype. Despite that most of efforts are focused on correcting the F508del-CFTR which causes intracellular retention of the mutant channel at the endoplasmic reticulum (ER), several additional strategies are emerging to rescue other (rarer mutants) which, in some populations, also have high prevalence. To this end, CFTR mutations are usually grouped into functional classes, towards a "mutation-specific" therapeutic approach by which mutations within the same functional class can be corrected by the same therapeutic strategy towards a "personalized medicine" approach [6].

Correspondence: mdamaral@fc.ul.pt

'BioFIG-Center for Biodiversity, Functional and Integrative Genomics Faculty of Sciences, University of Lisboa, Campo Grande, 1749-016 Lisboa, Portugal

Full list of author information is available at the end of the article

\section{Materials and methods/ results}

To apply such strategy CFTR mutations are thus classified into six main functional categories $[7,8]$, namely: $i$ ) class I mutations (often mutations generating premature stop codons, e.g., R1162X) prevent protein production; ii) class II mutations (includes F508del) cause intracellular retention and premature degradation, thus preventing mutant CFTR from reaching the cell surface; iii) class III mutants (e.g., G551D) cause impairment in the channel gating (i.e., decreased open probability); iv) class IV mutants have substantially reduced flow of $\mathrm{Cl}^{-}$ions through the CFTR channel (e.g., R334W); v) class V mutants include mostly alternative splicing mutants (e.g., 3272-26A>G) which allow synthesis of some normal CFTR mRNA (and protein), albeit at very low levels; and $v i$ ) class VI mutants (e.g., c.120del23 [9] or membrane-rescued F508del) impair the plasma membrane stability of CFTR.

\section{Conclusions}

Several therapeutic strategies adopting this "mutation-specific" approach are currently under experimental testing or clinical trial $[3,6]$. Based on the current "drug pipeline", these are expected to rise in numbers very soon.

\section{Acknowledgements \\ Work in the author's laboratory is supported by research grants, namely: strategic grants from FCT, Portugal PEst-OE/BIA/UI4046/2011 (to BioFIG), PIC/IC/83103/2007, PTDC/SAU-GMG/122299/2010 and from European Union grant TargetScreen2-FP6-2005-LH-7-037365}

\section{Author details}

${ }^{1}$ BioFIG-Center for Biodiversity, Functional and Integrative Genomics Faculty of Sciences, University of Lisboa, Campo Grande, 1749-016 Lisboa, Portugal. ${ }^{2}$ Centre of Human Genetics, National Institute of Health, Av. Padre Cruz, 1649-016 Lisboa, Portugal.

Published: 22 November 2012 


\section{References}

1. Welsh MJ, Ramsey BW, Accurso FJ, Cutting GR: Cystic Fibrosis. In The Metabolic Basis of Inherited Disease.. 8 edition. New York: McGraw-Hill;Scriver CR, Beaudet AL, Sly WS, Valle D 2001:5121-5188.

2. De Boeck K, Wilschanski M, Castellani C, Taylor C, Cuppens H, Dodge J, Sinaasappel M: Cystic fibrosis: terminology and diagnostic algorithms. Thorax 2006, 61:627-635.

3. Amaral MD: Targeting CFTR: how to treat cystic fibrosis by CFTRrepairing therapies. Curr Drug Targets 2011, 12:683-693.

4. The CFTR Mutation Database. 2012 [http://www.genet.sickkids.on.ca/app].

5. Collins FS: Cystic fibrosis: molecular biology and therapeutic implications. Science 1992, 256:774-779.

6. Amaral MD, Kunzelmann K: Molecular targeting of CFTR as a therapeutic approach to cystic fibrosis. Trends Pharmacol Sci 2007, 28:334-341.

7. Welsh MJ, Smith AE: Molecular mechanisms of CFTR chloride channel dysfunction in cystic fibrosis. Cell 1993, 73:1251-1254

8. Zielenski J, Tsui LC: Cystic fibrosis: genotypic and phenotypic variations. Annu Rev Genet 1995, 29:777-807.

9. Ramalho AS, Lewandowska MA, Farinha CM, Mendes F, Goncalves J, Barreto C, Harris A, Amaral MD: Deletion of CFTR translation start site reveals functional isoforms of the protein in CF patients. Cell Physiol Biochem 2009, 24:335-346.

doi:10.1186/1750-1172-7-S2-A19

Cite this article as: Amaral: Finding new medicines to fight CF: multiple steps of a success story. Orphanet Journal of Rare Diseases 2012

7(Suppl 2):A19.

\section{Submit your next manuscript to BioMed Central} and take full advantage of:

- Convenient online submission

- Thorough peer review

- No space constraints or color figure charges

- Immediate publication on acceptance

- Inclusion in PubMed, CAS, Scopus and Google Scholar

- Research which is freely available for redistribution

Submit your manuscript at www.biomedcentral.com/submit 